\title{
SOIL REACTION AND ABSORPTION OF SILICON BY RICE
}

\author{
Mônica Sartori de Camargo ${ }^{1 *}$; Hamilton Seron Pereira ${ }^{2}$; Gaspar Henrique Korndörfer ${ }^{3}$; \\ Angélica Araújo Queiroz ${ }^{4}$; Caroline Borges dos Reis ${ }^{5}$ \\ ${ }^{1}$ APTA-Pólo Regional Centro Sul, Unidade de Pesquisa e Desenvolvimento de Tietê, Rod. SP 127, km 69, C.P. 18 - \\ 18300-000 - Tietê, SP - Brasil. \\ ${ }^{2}$ UFG - Centro de Ciências Agrárias e Biológicas Campus de Jataí - Rod. BR 364 - km 192 - Zona Rural - \\ 75800-000 - Jataí, GO - Brasil. \\ ${ }^{3}$ UFU - Instituto de Ciências Agrárias, C. P. 593 - 38400-902 - Uberlândia, MG - Brazil. \\ ${ }_{5}^{4}$ UFU - Programa de Pós-Graduação em Agronomia. \\ ${ }^{5}$ Graduate student University of Florida - Soil and Water Science Department - 1061 NW 122nd terrace - \\ Newberry, FL 32669 - United States of America. \\ *Corresponding author <mscamarg@yahoo.com.br>
}

\begin{abstract}
The solubility and availability of silicon can be influenced by soil reaction. A pot experiment with a clayey textured Rhodic Acrustox was conducted under greenhouse conditions to evaluate the effect of soil reaction on silicon availability to rice plants. The experiment was set up in a completely randomized design, using a factorial scheme $(4 \times 4)$ with four materials (calcitic lime, calcium and magnesium silicate, pure silicic acid, and wollastonite), four rates (0, 2500, 5000 and 7500 mg per 5 kg-pot) and four replicates. After 60 days, dry matter yield and silicon absorption by the rice shoot plants, $\mathrm{pH}_{\mathrm{CaCl} 2}$, and soluble silicon $\left(0.5 \mathrm{~mol} \mathrm{~L}^{-1}\right.$ acetic acid and $\left.0.01 \mathrm{~mol} \mathrm{~L}^{-1} \mathrm{CaCl}_{2}\right)$ in the soil were evaluated. The materials increased soil $\mathrm{pH}$ as the applied rates increased, except silicic acid. Soluble silicon extracted by $0.5 \mathrm{~mol} \mathrm{~L}^{-1}$ acetic acid also increased with applied rates. For calcium chloride, soluble silicon increased in the soil only with wollastonite and calcium and magnesium silicate, agreeing with its total content. Silicon absorption by the above-ground part of the rice plants was linearly correlated with rates of wollastonite, followed by calcium and magnesium silicate, silicic acid and calcitic lime. Soil $\mathrm{pH}$ increase with lime was not sufficient to provide silicon to the rice. The $0.01 \mathrm{~mol} \mathrm{~L}$ ${ }^{1} \mathrm{CaCl}_{2}$ soluble silicon had the best correlation with silicon absorption by plants. More studies are necessary under field conditions and other soils to corroborate the presented results.
\end{abstract}

Key words: Oriza sativa, soil, calcitic lime, silicate

\section{REAÇÃO DO SOLO E ABSORÇÃO DE SILÍCIO PELO ARROZ}

RESUMO: A solubilidade e disponibilidade de silício podem ser influenciadas pela reação do solo. Com o objetivo de estudar o efeito da reação do solo sobre a disponibilidade de silício para a cultura do arroz, foi conduzido experimento em Latossolo Vermelho álico textura argilosa em casa-de-vegetação. O experimento foi conduzido em fatorial $4 \times 4$, delineamento em blocos inteiramente casualizados e quatro repetições. Quatro materiais (calcário, silicato de cálcio e magnésio, ácido silícico puríssimo e wollastonita) foram aplicados em doses equivalentes a 0,2500, 5000, $7500 \mathrm{mg}$ por vaso de $5 \mathrm{~kg}$. Após 60 dias, foram avaliadas produção de matéria seca, absorção de silício da parte aérea do arroz, $\mathrm{pH}_{\mathrm{CaCl} 2}$, silício extraído em ácido acético $\left(0,5 \mathrm{~mol} \mathrm{~L}^{-1}\right)$ e $\mathrm{CaCl}_{2}\left(0,01 \mathrm{~mol} \mathrm{~L}^{-1}\right)$ no solo. Os materiais aumentaram o $\mathrm{pH}$ do solo com as doses, exceto o ácido silícico. O silício solúvel em ácido acético foi crescente com as doses dos materiais. Para o $\mathrm{CaCl}_{2}$, apenas houve aumento de silício solúvel no solo com as doses de wollastonita e silicato de cálcio e magnésio, concordando com seu teor total. A absorção de silício pela parte aérea do arroz foi linearmente crescente com as doses da wollastonita, seguida do silicato de cálcio e magnésio, ácido silícico e calcário. O aumento do pH do solo com calcário não foi suficiente para fornecer silício ao arroz. O silício extraído com $\mathrm{CaCl}_{2} 0,01 \mathrm{~mol} \mathrm{~L}^{-1}$ apresentou maior correlação com a absorção de silício pelas plantas. Mais estudos são necessários em condições de campo e outros solos para corroborar os resultados apresentados.

Palavras-chave: Oriza sativa, solo, calcário, silicato

\section{INTRODUCTION}

Silicon is considered a beneficial element for higher plants (Marschner, 1995), being fundamental for rice production. Silicon fertilization has been proclaimed for highly weathered soils used for Brazilian 
agriculture in the last years, even though it is commonly used as a lime in Europe and as a silicate fertilizer in Japan, Korea, Hawaii and China since 1955 (Takahashi et al., 1990; Nayar et al., 1977).

Silicon absorption by plants occurs as monosilicic acid $\left(\mathrm{H}_{4} \mathrm{SiO}_{4}\right)$, being proportional to the $\mathrm{Si}$ concentration in soil solution (Jones \& Handreck, 1967; Fox et al., 1967) for monocotyledons. It behaves as a very weak acid, and even in $\mathrm{pH} 7.0$, only $2 \mathrm{mg} \mathrm{kg}{ }^{-1}$ are ionized $\left(\mathrm{H}_{3} \mathrm{SiO}_{4}^{-}\right)$; as $\mathrm{pH}$ increases the degree of ionization increases (Jones \& Handreck, 1965). Monosilicic acid concentration in soil solution is variable, from 1 to $100 \mathrm{mg} \mathrm{dm}^{-3} \mathrm{SiO}_{2}$ (Raven, 1983), related with clay content (Raij \& Camargo, 1973), iron and aluminum oxides (Freitas et al., 1977) and pH (Beckwith \& Reeve, 1963; Jones \& Handreck, 1965). Among these factors, soil $\mathrm{pH}$ can be altered with liming materials, modifying the solubility of the monosilicic acid. This fact is important for rice, once maximum silicon absorption occurs within the 4.7-7.6 pH range (Cheong, 1982).

Silicon availability to plants is evaluated by extracting solutions with acetic acid $0.5 \mathrm{~mol} \mathrm{~L}^{-1}$ (Snyder, 2001; Korndörfer et al., 2001) and $0.01 \mathrm{~mol} \mathrm{~L}^{-1} \mathrm{CaCl}_{2}$ solution (Berthelsen et al., 2002). The $\mathrm{pH}$ of the extractant is also fundamental for monosilicic acid solubility, just as soil pH is important for soil solution concentration and silicon absorption by plants. Not enough silicate and lime comparative studies are available to prove if just the $\mathrm{pH}$ increase is able to provide this element to rice growing in soils with low silicon concentration, causing doubts about the effectiveness of silicate fertilizations. The objective was to evaluate the effect of soil reaction on silicon availability to rice.

\section{MATERIAL AND METHODS}

The experiment was carried out in a greenhouse with potted rice (5 $\mathrm{kg}$ dry soil capacity) using surface samples (0-0.2 m) of a Rhodic Acrustox. The soil chemical characteristics were: $\mathrm{pH}_{\mathrm{CaCl} 2} 4.4 ; \mathrm{P}$ $\left(\mathrm{mg} \mathrm{dm}^{-3}\right) 1.6$ (extracted by $\mathrm{H}_{2} \mathrm{SO}_{4} 0.025 \mathrm{~mol}_{\mathrm{c}} \mathrm{dm}^{-3}+$ $\left.\mathrm{HCl} 0.05 \mathrm{~mol}_{\mathrm{c}} \mathrm{dm}^{-3}\right) ; \mathrm{Si}-0.5 \mathrm{~mol} \mathrm{~L}^{-1}$ acetic acid $\left(\mathrm{mg} \mathrm{dm}^{-3}\right) 7.0 ; \mathrm{Al}\left(\mathrm{mmol}_{\mathrm{c}} \mathrm{dm}^{-3}\right)$ 6; $\mathrm{Ca}\left(\mathrm{mmol}_{\mathrm{c}} \mathrm{dm}^{-3}\right)$
2; $\mathrm{Mg}\left(\mathrm{mmol}_{\mathrm{c}} \mathrm{dm}^{-3}\right) 1 ; \mathrm{K}\left(\mathrm{mg} \mathrm{dm}^{-3}\right) 49,8$, Sum of bases $\left(\mathrm{mmol}_{\mathrm{c}} \mathrm{dm}^{-3}\right) 4$; effective CEC $\left(\mathrm{mmol}_{\mathrm{c}} \mathrm{dm}^{-3}\right)$ 10; CEC pH $7.0\left(\mathrm{mmol}_{\mathrm{c}} \mathrm{dm}^{-3}\right)$ 49.2; V (\%) 8.0; $\mathrm{m}$ (\%) 60; and organic matter $\left(\mathrm{g} \mathrm{kg}^{-1}\right) 36$. The physical characteristics were: very coarse $\left(\mathrm{g} \mathrm{kg}^{-1}\right)$ 80; fine coarse $(\mathrm{g}$ $\left.\mathrm{kg}^{-1}\right) 38$, loam $\left(\mathrm{g} \mathrm{kg}^{-1}\right) 124$, clay $\left(\mathrm{g} \mathrm{kg}^{-1}\right) 758$. The total contents of $\mathrm{SiO}_{2}, \mathrm{Al}_{2} \mathrm{O}_{3}, \mathrm{Fe}_{2} \mathrm{O}_{3}\left(\mathrm{~g} \mathrm{~kg}^{-1}\right)$ and $\mathrm{Ki}\left(\mathrm{SiO}_{2} /\right.$ $\left.\mathrm{Al}_{2} \mathrm{O}_{3} \times 1.7\right)$ were $178,282,108$ and 1.8 respectively.

The experiment was set up in a completely randomized design, using a factorial scheme $(4 \times 4)$ with four materials (calcitic lime, calcium and magnesium silicate, pure silicic acid, and wollastonite), four rates ( 0 , 2500, 5000 and $7500 \mathrm{mg}$ per pot) and four replicates. Rates of the materials were not corrected by $\mathrm{EqCaCO}_{3}$. The maximum rate of materials was defined as a function of the need of liming for this soil $\left(3 \mathrm{t} \mathrm{ha}^{-1}\right)$, calculated using the aluminum neutralization method described by Ribeiro et al. (1999). Additionally, two lower rates equivalent to 1 and $2 \mathrm{t} \mathrm{ha}^{-1}$ were used in this experiment. The materials were characterized regarding their origin, total $\mathrm{Si}, \mathrm{Ca}$, and $\mathrm{Mg}$ contents, and Neutralizing Power (NP) calculated and determined (Table 1). They were dried and sift through a $0.297-\mathrm{mm}$ screen.

The soil samples were air dried, sift through a 5-mm screen and homogenized. Each pot $(5 \mathrm{~kg}$ of soil) was fertilized with $5.825 \mathrm{~g}$ of superphosphate, $2.625 \mathrm{~g}$ of ammonium sulfate, $1.3125 \mathrm{~g}$ of $\mathrm{KCl}, 0.2625$ $\mathrm{g}$ of FTE e $1.595 \mathrm{~g}$ of $\mathrm{MgCl}$ at sowing time and incorporated with the treatments. The rice seeds (Formoso variety) were sown at the rate of 20 seeds per pot. Thinning was performed ten days after germination, leaving 10 plants per pot. The surface fertilization took place 30 days after sowing with $2.62 \mathrm{~g}$ of ammonium sulfate per pot. The soil moisture, after sowing, was kept close to field capacity, using deionized water. Field capacity was determined according to Korndörfer et al. (1999).

Rice shoot was harvested 60 days after sowing. Plant material was dried, weighed and ground; silicon determination was made as described by Elliot \& Snyder (1991). The biomass was evaluated based on dry matter production and the accumulated $\mathrm{Si}$ (uptake) was determined multiplying Si concentration by dry matter weight.

Table 1 - Characteristics of materials ( $\mathrm{NP}=$ Neutralizing power $)$.

\begin{tabular}{|c|c|c|c|c|c|c|}
\hline Treatment & Origin & $\mathrm{SiO}_{2}$ & $\mathrm{CaO}$ & $\mathrm{MgO}$ & $\begin{array}{c}\mathrm{NP} \\
\text { Calculated } \\
\end{array}$ & $\begin{array}{c}\mathrm{NP} \\
\text { Determined } \\
\end{array}$ \\
\hline & & & $\mathrm{g} \mathrm{kg}^{-1}$ & & $\mathrm{CaCO}_{3} \mathrm{Eq}(\%)$ & \\
\hline Wollastonite & Vanzil & 502.7 & 424.3 & 1.9 & 76.4 & 73.5 \\
\hline $\mathrm{Ca}$ and $\mathrm{Mg}$ silicate & Recmix & 232.2 & 367.0 & 94.3 & 89.1 & 87.5 \\
\hline Lime & Calcitic & $-\ldots$ & 438.0 & 6.6 & 80.1 & 77.4 \\
\hline Silic acid & Merck & 28.7 & $-\cdots--$ & $-\cdots-$ & $-\cdots-$ & $-\ldots-$ \\
\hline
\end{tabular}


After harvest, soil samples from the pots were air dried and analyzed for $\mathrm{pH}_{(\mathrm{CaC} 12)}$ (EMBRAPA, 1999), soluble silicon concentration using $0.5 \mathrm{~mol} \mathrm{~L}^{-1}$ acetic acid (Korndorfer et al., 1999) and $0.01 \mathrm{~mol} \mathrm{~L}^{-1} \mathrm{CaCl}_{2}$. Ten grams of soil were shaken for 1 hour with 100 $\mathrm{mL}$ of acetic acid or $\mathrm{CaCl}_{2}$. After that, the solution was decanted after a 15- minute waiting period; the solution was filtrated, and then left resting for 12 hours at room temperature. Si determination in different soil extracts was performed by beta molybdosilicic complex formation (Kilmer, 1965), using a spectrophotometer at $660 \mathrm{~nm}$. The statistical analyses for dry matter production, soil $\mathrm{pH}_{\mathrm{CaCl} 12}$, soluble $\mathrm{Si}$ extracted by $0.5 \mathrm{~mol} \mathrm{~L}^{-1}$ acetic acid and $0.01 \mathrm{~mol} \mathrm{~L}^{-1} \mathrm{CaCl}_{2}$ were made using the SAS (Statistical Analysis System, 1996). The analyses of variance were made applying the $\mathrm{F}$ test. The materials were compared by the Tukey test at $5 \%$. A polynomial regression was used to analyze the effects of rates of materials.

\section{RESULTS AND DISCUSSION}

Soil pH increased to $5.9 ; 6.6$ and 6.3 at the rates equivalent to $7500 \mathrm{mg}$ per pot of wollastonite, calcium and magnesium silicate and lime, respectively. These $\mathrm{pH}$ values were important to provide an adequate range (4.7-7.6) to maximum silicon absorption by rice (Cheong, 1982). The $\mathrm{pH}$ increase is explained by enhanced hydroxyl $\left(\mathrm{OH}^{-}\right)$concentration from the materials (Alcarde, 1992). These results are in agreement with those found for wollastonite (Korndörfer et al., 1999), lime (Alcarde, 1992), and calcium and magnesium silicate (Dalto, 2003; Korndörfer et al., 2002; Pereira et al., 2004), since these materials are formed basically by $\mathrm{CaSiO}_{3}$ (Coelho, 1998) or $\mathrm{CaCO}_{3}$ (Alcarde, 1992). On the other hand, silicic acid did not promote changes on $\mathrm{pH}$ values (mean soil $\mathrm{pH}=3.93$ ), also observed by Benedito (2004) and Chagas (2004) growing rice in medium clayey textured soils.

The materials presented increases in acetic acid extracted silicon, except silic acid (Figure 1). There is a strong correlation between soluble silicon in acetic acid and soil pH (Figure 2). Dalto (2003), using lime on sugarcane straw, observed high silicon concentrations in $0.5 \mathrm{~mol} \mathrm{~L}^{-1}$ acetic acid than water extracted from soil after soybean harvest. It was also observed by Camargo et al. (2005), working with different soils treated with lime after 90 days of incubation. These data are in agreement with other articles that already showed the efficiency of the acid solutions compared to neutral-pH extracting solutions (Berthelsen et al., 2002; Sumida, 2002).

The higher extraction power of acetic acid is explained by the lowest $\mathrm{pH}(1.0-2.0)$ necessary for molybdosilicic complex formation (Kilmer, 1965). The change in soil $\mathrm{pH}$ contributed to a higher silicon extraction by the acetic acid, once this difference was higher with rates of materials. This could explain the high silicon concentrations in lime, wollastonite and calcium and magnesium silicate. Additionally, the acetic acid is able to extract non available silicon present in some materials such as calcium and magnesium silicate, but it is not true for wollastonite (Pereira et al., 2004). Xu et al. (2001) attributed to calcium silicate dissolution the high silicon extracted with acid extracting solution $(\mathrm{pH} 4)$ in calcareous soils. According to Brown \& Mahler (1987), acidity and anions could additively impact $\mathrm{Si}$ release from soils, as showed by Wang et al. (2004).

The soluble silicon concentration extracted by $0.01 \mathrm{~mol} \mathrm{~L}^{-1} \mathrm{CaCl}_{2}$ increased in soils treated with wollastonite and calcium and magnesium silicate. Silicic acid and lime did not increase soluble silicon concen-

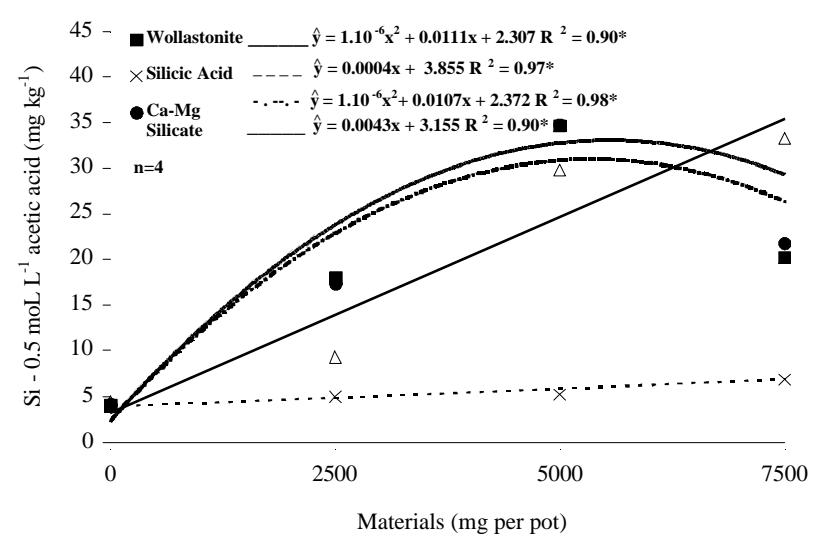

Figure 1 - Silicon content in $0.5 \mathrm{~mol} \mathrm{~L}^{-1}$ acetic acid in soil treated with varying rates of the indicated materials after 60 days of rice cultivation (* significant $P<0.05 ; \mathrm{n}=$ number of observations per point).

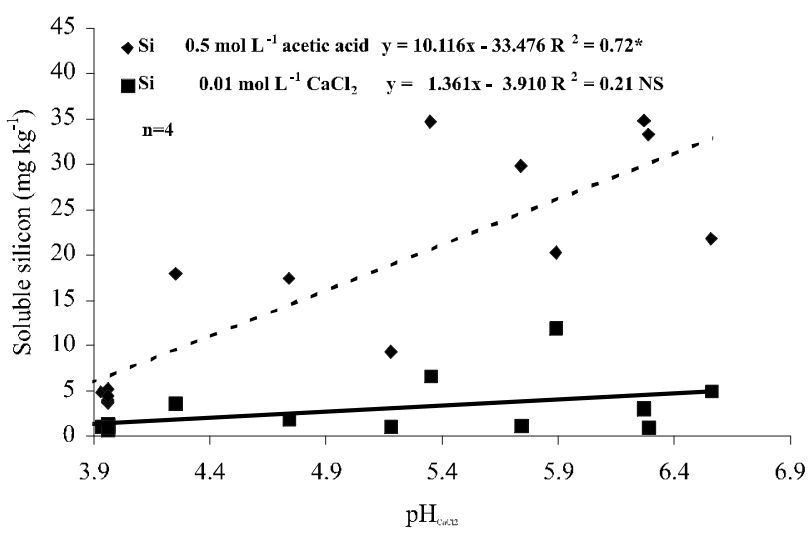

Figure 2 - Correlation between soil $\mathrm{pH}_{\mathrm{CaCl} 2}$ values and soluble $\mathrm{Si}$ extracted by $0.5 \mathrm{~mol} \mathrm{~L}^{-1}$ acetic acid and $0.01 \mathrm{~mol} \mathrm{~L}^{-1}$ calcium chloride (NS = non significant; *significant $P<0.05 ; \mathrm{n}=$ number of observations per point). 
tration extracted by $\mathrm{CaCl}_{2}$ in the soil (Figure 3). Results are in agreement with total silicon concentration in those materials (Table 1). The $\mathrm{pH}$ changes did not show marked interference as observed with the acetic acid extractant (Figure 2). Once again, these results showed low solubility of silicon form silicic acid to the soil solution, agreeing with Chagas (2004).

The dry matter production increased with rates of wollastonite, followed by calcium and magnesium silicate, lime, and silicic acid (Figure 4), reaching similar results at equivalent rates to $7500 \mathrm{mg}$ per $5 \mathrm{~kg}$ pot. Otherwise, silicon absorption by the rice plants (Figure 5) was a good indicator of total silicon of materials (Table 1). Silicic acid provided low silicon uptake as a consequence of its low silicon content, as already shown by Benedito (2004) and Chagas (2004).

The $\mathrm{pH}$ increase propitiated higher silicon uptake with rates of wollastonite and calcium and magnesium silicates (Figure 5), once they are silicon

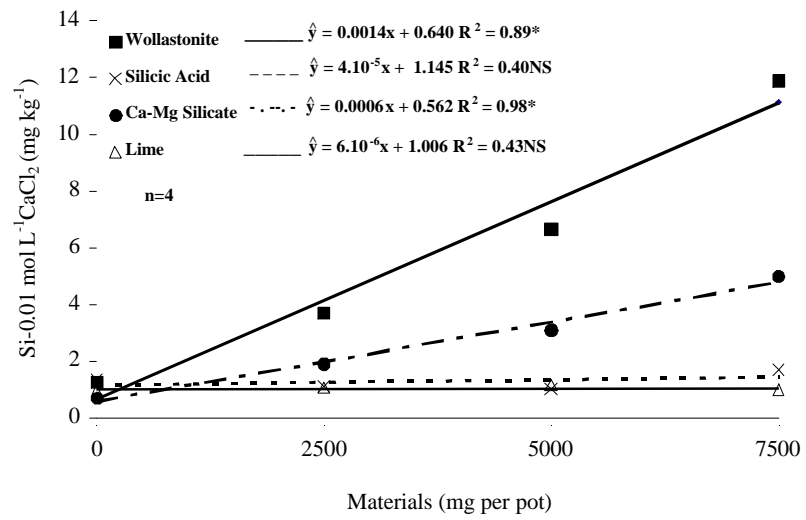

Figure 3 - Silicon concentration in $0.01 \mathrm{Mol} \mathrm{L}^{-1}$ calcium chloride in soil treated with varying rates of the indicated materials after 60 days of rice cultivation $(\mathrm{NS}=$ non significant; *significant $P<0.05 ; \mathrm{n}=$ number of observations per point).

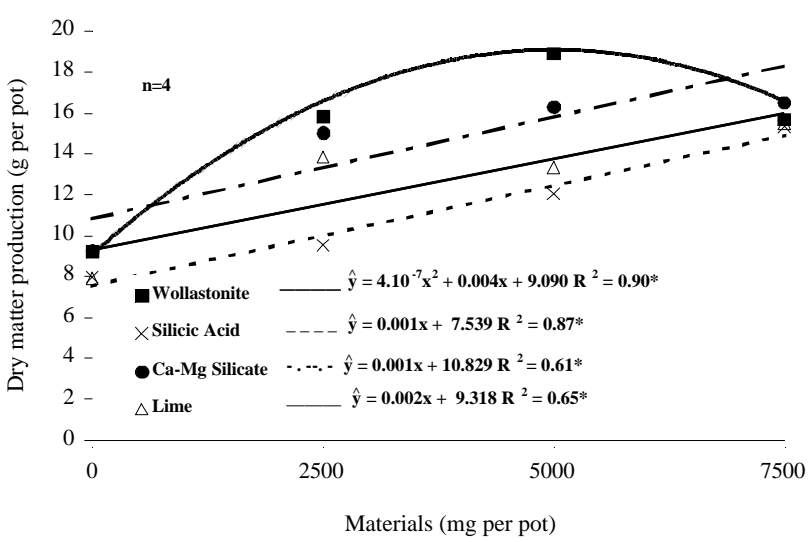

Figure 4 - Dry matter yield of the rice cultivated in pots treated with varying rates of the indicated materials (*significant $P<0.05 ; \mathrm{n}=$ number of observations per point). sources and liming materials. On the contrary, the lime treatment provided low increase of silicon absorption. It is necessary to choose adequate extracting solutions to measure available silicon to plants without overestimating results.

The $0.01 \mathrm{~mol} \mathrm{~L}^{-1} \mathrm{CaCl}_{2}$ extractant presented the best correlation between soluble silicon concentration and plant silicon concentration (Figure 6), agreeing

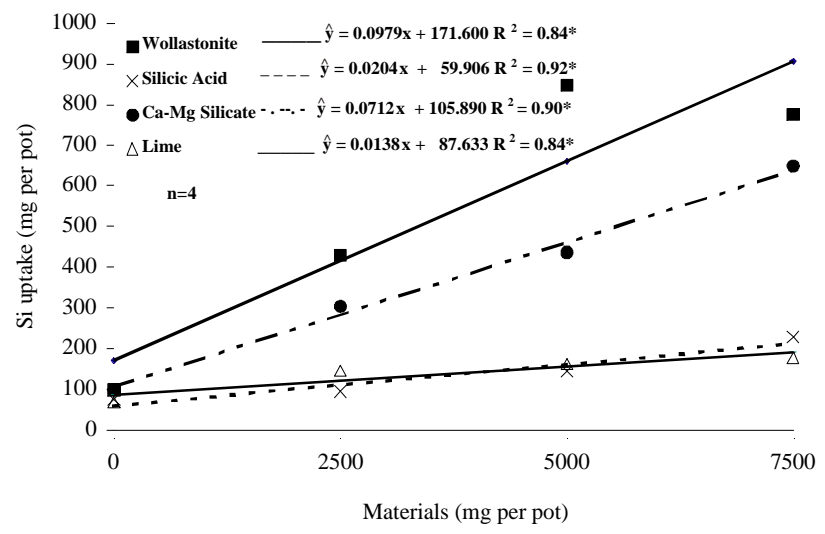

Figure 5 - Silicon absorbed by the above-ground of the rice plant cultivated in pots treated of varying rates of the indicated materials (* significant $P<0.05 \mathrm{n}=$ number of observations per point).

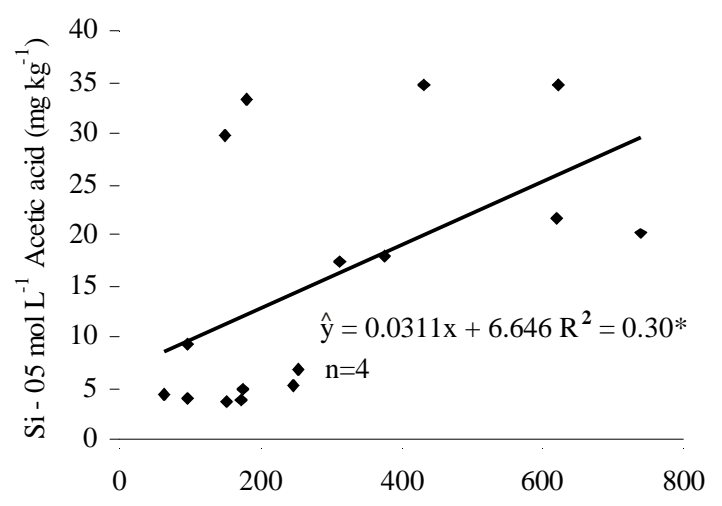

14 - Si absorption (mg per pot)

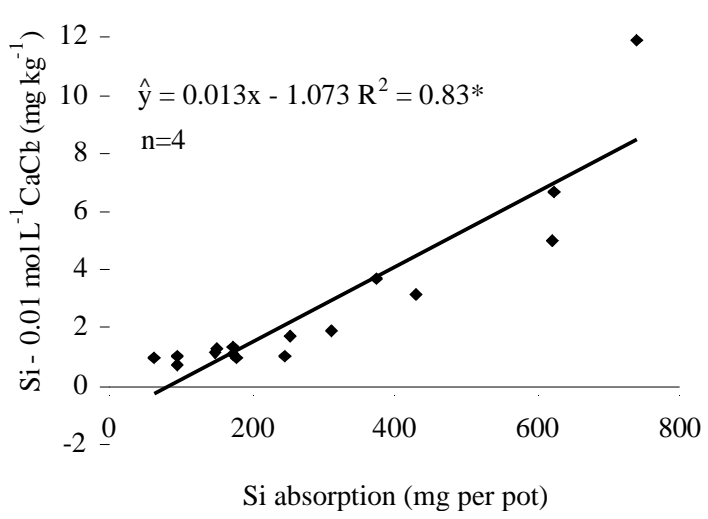

Figure 6 - Correlation between Si absorbed by the rice plants and soluble Si extracted by $0.5 \mathrm{~mol} \mathrm{~L}^{-1}$ acetic acid and 0.01 mol L-1 calcium chloride (* significant $P<0.05 ; \mathrm{n}=$ number of observations per point). 
with Pereira et al. (2004) for the rice crops. These results are also in agreement with silicon total concentration of the studied materials (Table 1).

Considering soil and plant data of this experiment and the lowest influence by soil $\mathrm{pH}$ compared with acetic acid, the $\mathrm{CaCl}_{2} 0.01 \mathrm{~mol} \mathrm{~L}^{-1}$ must be included in future research to indicate silicon availability to rice plants. Additionally, the $\mathrm{pH}$ increase with lime is not sufficient to provide highest silicon uptake by rice, comparing Wollastonite and $\mathrm{Ca}-\mathrm{Mg}$ silicate.

\section{REFERENCES}

ALCARDE, J.C. Corretivos da acidez dos solos: características e interpretações técnicas. São Paulo: ANDA. 1992. (Boletim Técnico, 6).

BECKWITH, R.S.; REEVE, R. Studies on soluble silica in soils. 1The sorption of silicon acid by soils and minerals. Australian Journal Soil Research, v.1, p.157-168, 1963.

BENEDITO, D.S. Interação boro x silício na nutrição, crescimento e produção do arroz. Lavras: UFLA, 2004. 62p. (Dissertação Mestrado).

BERTHELSEN, S.; NOBLE, A.; KINGSTON, G.; HURNEY, A.; RUDD, A. Effect of Ca-silicate amendments on soil chemical properties under a sugarcane cropping system. In: SILICON IN AGRICULTURE CONFERENCE, 2., Tsuruoka, Japão, 2002. Proceedings. Tsuruoka: Japanese Society of Soil Science and Plant Nutrition, 2002. p.57.

BROWN, T.H.; MAHLER, R.L. Effects of phosphorus and acidity levels on levels of silica extracted from a Palouse silt loam. Soil Science Society of America Journal, v.59, p.39-45, 1987.

CAMARGO, M.S. de; KORNDÖRFER, G.H.; CORRÊA, G.F.; PEREIRA, H.S.; SCALIA, D.; RESENDE, R.H. Extratores de silício em solos: influência do calcário e fósforo. Bioscience Journal, v.21, p.9-19, 2005.

CHAGAS, R.S.C. Avaliação de fontes de silício para as culturas do arroz e milheto. Piracicaba: USP/CENA, 2004. 100p. (Tese Doutorado).

CHEONG, B.T. Some significant functions of silicon to higher plants. Journal Plant Nutrition, v. 5, p.1345-1353, 1982.

COELHO, P.E. Da escória ao vidro. Revista Limpeza Pública, v.49, p.36-45, 1998.

DALTO, G. Manejo de silicato e calcário em soja cultivada sobre palhada de cana-de-açúcar. Uberlândia: UFU, 2003. 90p. (Dissertação - Mestrado).

ELLIOTT, C.L.; SNYDER, G.H. Autoclave-induced digestion for the colorimetric determination of silicon in rice straw. Journal of Agricultural and Food Chemistry, v.39, p.1118-1119, 1991.

EMPRESA BRASILEIRA DE PESQUISA AGROPECUÁRIA. Manual de análises químicas de solos, plantas e fertilizantes. Brasília: Embrapa Comunicação para Transferência de Tecnologia, 1999. 370p.

FOX, R.L.; LEVA, J.A.; YOUNG, O.P.; PLUNCKNETT, U.L.; HERMAW, G.D. Soil and plant silicon and silicate response by sugarcane. Soil Science Society of America Proceedings, v.31, p.775-779, 1967.

FREITAS, L.C.; COSTA FILHO, J.F. da; ALOISI, R.R.; MELO, W.J. Contribuição ao estudo da sílica solúvel em alguns perfis de solos. Científica, v.5, p.296-305, 1977.
JONES, J.H.; HANDRECK, K.A. Silica in soils, plants, and animals. Advances in Agronomy, v.19, p.107-149, 1967

JONES, J.H.; HANDRECK, K.A. Studies of silica in the oat plant. III-Uptake of silica from soils by the plant. Plant and Soil, v.23, p.79-96, 1965 .

KILMER, V.J. Silicon. In: BLACK, C.A. (Ed.). Methods of soil analysis. Madison: ASA, 1965. pt1, p.959-962. (Agronomy, 9).

KORNDÖRFER, C.M.; KORNDÖRFER, G.H.; CARDOSO, K. Aplicação do silicato de cálcio na recuperação de pastagem degradada de Brachiaria decumbens. In: REUNIÃO BRASILEIRA DE FERTILIDADE DO SOLO E NUTRIÇÃO DE Plantas, 25., Rio de Janeiro. Proceedings. Rio de Janeiro: SBCS, 2002. p.8-11.

KORNDÖRFER, G.H.; COELHO, N.M.; SNYDER, G.H.; MIZUTANI, C.T. Avaliação de métodos de extração de silício para solos cultivados com arroz de sequeiro. Revista Brasileira de Ciência do Solo, v.23, p.101-106, 1999.

KORNDÖRFER, G.H.; SNYDER, G.H.; ULLOA, M.; POWELL, G.; DATNOFF, L.E. Calibration of soil and plant silicon analysis for rice production. Journal of Plant Nutrition, v.24, p.10711084, 2001.

MARSCHNER, H. Mineral nutrition of higher plants. 2.ed. London: Academic Press, 1995. 889p.

NAYAR, P.K.; MISRA, A.K.; PATNAIK, S. Evaluation of silicasupplying power of soils for growing rice. Food and Fertilizer Technology Center, v.23, p.197-221, 1977.

PEREIRA, H.S.; KORNDÖFER, G.H.; VIDAL, A.A.; CAMARGO, M.S. Silicon sources for the rice plants. Scientia Agricola, v.61, p.522-528, 2004.

RAIJ, B. van; CAMARGO, O.A. Sílica solúvel em solos. Bragantia, v.32, p.223-236, 1973.

RAVEN, J.A. The transport and function of silicon in plants. Biological Reviews of Cambridge Philosophical Society, v.58, p.179-207, 1983.

RIBEIRO, A.C.; GUimarães, P.T.G.; ALVAREZ V., V.H.; Recomendações para o uso de corretivos e fertilizantes em Minas Gerais. $5^{\text {a }}$ Aproximação. Viçosa: UFV, 1999. 359p.

SAS Institute INC. The SAS-system for windows: release 6.11 (software). Cary: SAS Institute, 1996.

SNYDER, G.H. Methods for silicon analysis in plants, soils and fertilizers. In: DATNOFF, L.E.; SNYDER, G.H.; KORNDÖRFER, G.H. Silicon in agriculture. Amsterdam: Elsevier, 2001. p.185-196.

SUMIDA, H. Plant available silicon in paddy soils. In: SILICON IN AGRICULTURE CONFERENCE, 2., Tsuruoka, Japão, 2002. Proceedings. Tsuruoka: Japanese Society of Soil Science and Plant Nutrition, 2002. p.43-49.

TAKAHASHI, E.; MA, J.F.; MIYAKE, Y. The possibility of silicon as an essential element for higher plants. Comments in Agriculture and Food Chemistry, v.2, p.99-122, 1990.

XU, G.; ZHAN, X.; CHUNHUA, L.; BAO, S.; LIU, X.; CHU, T. Assessing methods of available silicon in calcareous soils. Communication in Soil Science and Plant Analysis, v.32, p.787-801, 2001.

WANG, J.J.; DODLA, S.K.; HENDERSON, R.E. Soil silicon extractability with seven selected extractants in relation to colorimetric and ICP determination. Soil Science, v.169, p.861-870, 2004.

Received March 20, 2006

Accepted March 02, 2007 